\title{
Membangun Game Edutainment "Pengenalan Komputer" Menggunakan Shuffle Random (SR) Dan Finite State Machine (FSM) Untuk Anak Tunagrahita Ringan
}

\author{
Heny Pratiwi, Ita Arfyanti, M. Za'iem Sururi \\ STMIK Widya Cipta Dharma \\ Jl. Prof. M. Yamin No.25 Samarinda Kalimantan Timur, (0541)736071 \\ henypratiwi@wicida.ac.id, qanita23@yahoo.com
}

\begin{abstract}
Research to build an Edutainment Game "Introduction to Computers" for mild retarded children is a study designed for teachers to deliver material to special school students (SLB) with special needs such as children with visual impairment, hearing impairment, mental retardation, intellectual disability, autism and blindness. . In this game the player will be presented with a variety of learning menus about "Computer Devices" and a game menu consisting of a guessing picture quiz to train memory, then there are typing games and labyrinth games to develop motor movements and increase students' responses and interests. Shuffle and Finite State Machine randomization algorithms will be applied in this study, with the aim of arranging the image position to be randomized in the learning menu and typing games as well as randomizing the position of the main characters and enemies in the labyrinth game made in three levels. This is done to improve students' learning and curiosity. The technology applied in this research is intelligent agent (intelligent system) which has a game agent character that will accompany children to learn and play.
\end{abstract}

Keywords: Game, Edutainment, Komputer, Shuffle Random, Finite State Machine

\begin{abstract}
Abstrak
Penelitian membangun Game Edutainment "Pengenalan Komputer" untuk anak tunagrahita ringan merupakan penelitian yang dirancang untuk memudahkan para guru untuk menyampaikan materi kepada para siswa-siswi SLB yang berkebutuhan khusus. Pada permainan ini pemain akan disajikan beragam menu belajar tentang "Perangkat Komputer" dan menu permainan yang terdiri dari kuis tebak gambar untuk melatih ingatan, lalu ada game mengetik dan game labirin untuk mengembangkan gerakan motorik dan meningkatkan respon serta minat siswa. Algoritma pengacakan Shuffle dan Finite State Machine akan diaplikasikan dalam penelitian ini, dengan tujuan susunan posisi gambar akan menjadi teracak pada menu belajar dan game mengetik serta mengacak posisi karakter utama dan musuh dalam game labirin yang dibuat dalam tiga level. Hal ini dilakukan untuk meningkatkan daya belajar dan rasa ingin tahu siswa. Adapun teknologi yang diterapkan yaitu sistem cerdas yang memiliki karakter game agent yang akan mendampingi anak belajar dan bermain.
\end{abstract}

Kata Kunci: Game, Edutainment, Komputer, Shuffle Random, Finite State Machine

\section{PENDAHULUAN}

Pendidikan mempunyai peranan yang sangat penting dalam kehidupan manusia. Seiring dengan kemajuan ilmu pengetahuan dan teknologi, maka diperlukan guru yang profesional yang dapat melaksanakan tugasnya sebagai pendidik, pengajar, pembimbing dan pelatih anak-anak bangsa di masa depan yang dapat memberikan arah pembelajaran yang aktif, kreatif, dan inovatif [1]. 
Pada saat ini penggunaan teknologi komputer dalam dunia pendidikan bukanlah hal yang asing bagi para pengajar, siswa-siswi maupun masyarakat luas. Berkaitan dengan hal tersebut, semakin berkembangnya teknologi informasi diera digital saat ini, mengaharuskan sekolah-sekolah bersaing dalam memberikan informasi dan pemberdayaan teknologi komputer, tujuannya untuk memperkuat persaingan dibidang ilmu teknologi maka dibutuhkan sarana pendidikan untuk menunjang ilmu pengetahuan para pelajar agar memaksimalkan metode pengajaran yang diterapkan.

Perkembangan teknologi informasi saat ini sejalan dengan perkembangan game yang beragam, mulai dari game strategy, adventure, arcade, puzzle, sport yang dikemas dalam playstation game maupun PC game dan akan sangat menarik bagi setiap orang khususnya bagi anak-anak. Meskipun banyak game yang telah dibuat atau berkembang di masyarakat umum masih banyak yang tidak atau jarang ada yang membuat game yang bertemakan edutainment (game edukasi yang menghibur)[2]. Edutainment penting bagi semua kalangan pada saat mereka bermain game bertemakan edutainment pada platform apa saja, disitu dengan tidak sengaja mereka akan mempelajari pengetahuan dalam bentuk permainan [3].

Edutainment sangat menarik untuk dikembangkan, salah satu jenis yang digemari adalah game dengan genre simulasi yang didukung dengan kecerdasan buatan yang menggunakan Shuffle Random (SR) dan Finite State Machine (FSM) untuk mendukung interaksi dengan pemain [4]. FSM terdiri dari serangkaian state yang menentukan keputusan. Berdasarkan pola yang dimiliki oleh game tersebut, pemain diharuskan untuk belajar sehingga dapat menyelesaikan permasalahan yang ada. Saat ini, ada banyak permainan yang mengedukasi sekaligus menghibur, sehingga memberikan inspirasi dalam pembuatan Edutainment "Pengenalan Komputer" sebagai media pembelajaran dengan teknik pengacakan dan pengembangan agen cerdas menggunakan Finite State Machine.

Dengan dibangunnya edutainment ini diharapkan para guru dapat terbantu dengan menarik minat anak tunagrahita ringan untuk belajar tentang perangkat komputer sambil bermain dengan menerapkan logika shuffle dalam permainan. Sedangkan intelligent agent akan memberikan respon, bertindak pada suatu kondisi tertentu sehingga terlihat seperti diri sendiri pada permainan labirin yang diimplementasikan dengan metode finite state machine.

\section{METODOLOGI PENELITIAN}

\subsection{Kerangka Berpikir}

Penelitian tentang game dengan teknik yang sama telah banyak dilakukan antara lain:

a. Penerapan Metode Finite State Machine Pada Game "The Relationship"[5].

b. Implementasi Finite State Machine (FSM) Dalam Agen Cerdas dan Penerapan Pengacakan Shuffle Dalam Edutainment "Ajut-Ajut Kids" Media Pembelajaran Muatan Lokal Bahasa Dayak [6]. 
c. Agen Cerdas Animasi Wajah Untuk Game Tebak Kata dengan metode Finite State Machine [7].

Pada penelitian Rahadian, game yang dibuat dengan mengimplementasikan metode Finite State Machine. Game ini merupakan sebuah game berbasis desktop genre petualangan dengan sub-genre simulasi dan menggunakan grafis 2 dimensi. Pengembangan game ini menggunakan tools Unity3D dan bahasa pemrograman C\#(Sharp).

Pada penelitian S Lailiyah, Edutainment "Ajut-ajut Kids" Media Pembelajaran Muatan Lokal Bahasa Dayak dengan Teknik Pengeacakan Shuffle Random dan Pengembangan Game Agent dengan Model Finite State Machine (FSM). Permainan yang mengasah kemampuan pemain untuk berpikir cepat menemukan dan menyusun huruf menjadi sebuah kata bahasa dayak, huruf atatu objek di dalam permainan ini diacak menggunakan algoritma acak posisi shuffle random agar permainan tidak statis dan membosankan. Permainan yang akan dibangun juga menerapkan Finite State Machine, dimana peran pendamping anak akan digantikan dengan adanya game agent. Agen permainan adalah karakter game yang dikontrol dengan cerdas memggunakan model logika berpikir Finite State Machine (FSM).

Pada penelitian Rahadian, game yang dibuat mengimplementasikan metode Finite State Machine ke dalam game agent. Tujuan penelitian adalah menciptakan agen cerdas yang dapat menentukan ekspresi dan komentar yang harus dilakukan oleh animasi wajah dan menerapkannya pada rangkaian manajemen game "kata". Permasalahan yang didapat terletak pada sulitnya mengintegrasikan animasi wajah dengan metode FSM terhadap game. Hasilnya yaitu terciptanya agen dengan wujud ekspresi wajah senang dan kecewa saat mengomentari langkah pemain permainan kata.

Sedangkan pada penelitian ini, membangun game edutainment "Pengenalan Komputer" dengan pengembangan menggunakan metode Shuffle Random (SR) dan Finite State Machine (FSM) untuk anak tunagrahita ringan. Permainan yang mengasah otak dengan menyajikan tiga jenis kegiatan yaitu kuis, game mengetik, dan game labirin. Untuk penerapan Algoritma Finite State Machine dititik beratkan didalam game labirin dengan melewati jalur yang liku-liku. Permainan ini untuk mengedukasi para siswa-siswi SLB agar menambah keminatan mereka dalam mengikuti pelajaran serta dengan penerapan Algoritma Finite State Machine pada game ini akan memudahkan para guru untuk menyampaikan materi bahan ajar kepada siswa-siswi sehingga memaksimalkan pemberian ilmu dengan menggunakan teknologi komputer. Berikut disajikan roadmap penelitian dari permainan edukasi dan pengembangan game intelligent agent dengan Finite State Machine. (Lihat Gambar 1). 


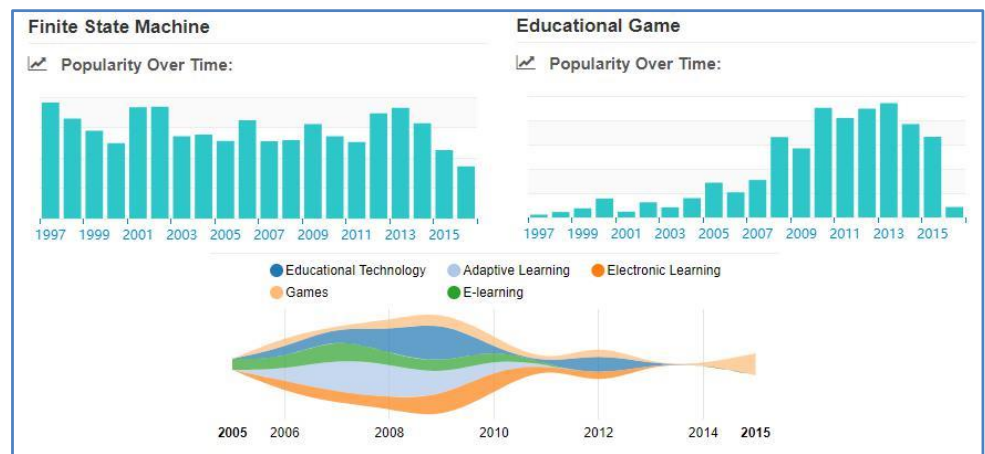

Gambar 1. Roadmap Penelitian

\subsection{Edutainment}

Penerapan edutainment bermula dari perkembangan video game yang sangat pesat dan menjadikannya sebagai media efektif yang interaktif dan banyak dikembangkan di perindustrian. Melihat kepopuleran jenis game tersebut, para pendidik berpikir bahwa mereka mempunyai kesempatan yang baik untuk menggunakan komponen rancangan game dan menerapkannya pada kurikulum dengan penggunaan industri berbasis game dan juga hiburan. Game harus memiliki desain antarmuka yang interaktif dan mengandung unsur menyenangkan.

\subsection{Shuffle Random}

Merupakan pengacakan urutan indeks dari sebuah record atau array, diibaratkan pengocokan pada dek kartu, dimana semua kartu dikocok sehingga susunannya teracak. Dalam bahasa pemrograman fungsi pengacakan shuffle tidak hanya dapat mengacak angka, tetapi juga dapat mengacak array string atau campuran string dan angka [8].

\subsection{Finite State Machine (FSM)}

Dalam perancangan AI untuk game, state machine merupakan teknik yang paling banyak dipergunakan untuk permasalahan decision making dan, sekaligus dengan scriptingnya, dipergunakan secara luas untuk merancang sistem decision making dalam game. State machine dikenal secara luas sebagai teknik untuk pemodelan fenomena atau kondisi berbasis event, termasuk penguraiannya, serta desain interface. Prinsip dari komponenkomponen yang terintegrasi dalam FSM ditunjukkan dalam gambar 2.

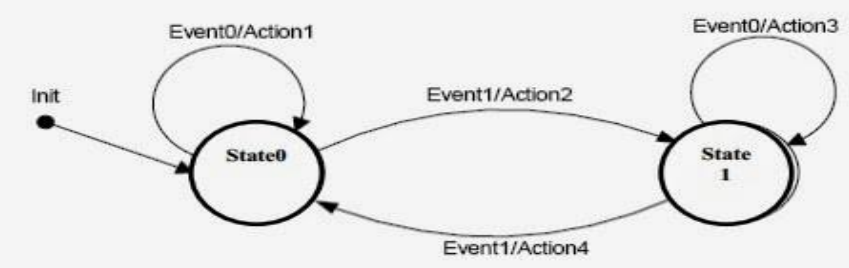

Gambar 2. Diagram Finite State Machine Sederhana 


\subsection{Artificial Intelligence (Kecerdasan Buatan)}

Definisi Artificial Intelligence (Kecerdasan Buatan) merupakan cabang dari ilmu komputer yang dalam merepresentasi pengetahuan lebih banyak menggunakan bentuk simbol-simbol daripada bilangan, dan memproses informasi berdasarkan metode heuristic atau dengan berdasarkan sejumlah aturan. Ada tiga tujuan kecerdasan buatan, yaitu, membuat komputer lebih cerdas, mengerti tentang kecerdasan, dan membuat mesin yang lebih. [9].

\subsection{Tunagrahita}

Tunagrahita adalah istilah yang digunakan untuk menyebut anak yang mempunyai kemampuan intelektual di bawah rata-rata. Dalam kepustakaan bahasa asing digunakan istilah-istilah mental retardation, mentally retarded, mental deficiency, mental defective, dan lain-lain. Istilah tersebut sesungguhnya memiliki arti yang sama yang menjelaskan kondisi anak yang kecerdasannya jauh di bawah rata- rata dan ditandai oleh keterbatasan intelegensi dan ketidak cakapan dalam interaksi sosial".

\section{HASIL DAN PEMBAHASAN}

\subsection{Tahapan Penelitian}

Penelitian dilaksanakan melalui beberapa tahapan pengembangan multimedia sebagai berikut:

1. Studi literatur mengenai proses pembuatan edutainment dan penerapan algoritma yang digunakan, serta mengumpulkan material-material pembuatan game.

2. Proses pengembangan edutainment dengan metode pengembangan sistem multimedia Multimedia Development Life Cycle (MDLC), mulai dari concept (Pengonsepan), design (pendesainan), material colecting (pengumpulan materi), dan assembly (pembuatan).

3. Pemasangan edutainment "pengenalan komputer" pada komputer atau laptop guru.

4. Melakukan pengujian sistem dengan black box dan beta testing berupa kuisioner serta mengkaji dokumen-dokumen tersebut.

5. Menganalisa hasil kuisioner dan pengkajian kembali terhadap penerapan Algoritma Finite State Machine dan algoritma posisi acak shuffle dalam edutainment.

6. Pendistribusian dan analisis kembali sampai hasil testing menghasilkan nilai persentasi yang memuaskan.

Setiap tahapan dilakukan secara berurutan mulai dari langkah pertama sampai langkah terakhir, setiap langkah yang telah selesai dikerjakan harus dilakukan pengkajian ulang, tertera dalam kerangka penelitian sebagai gambar 3 berikut : 


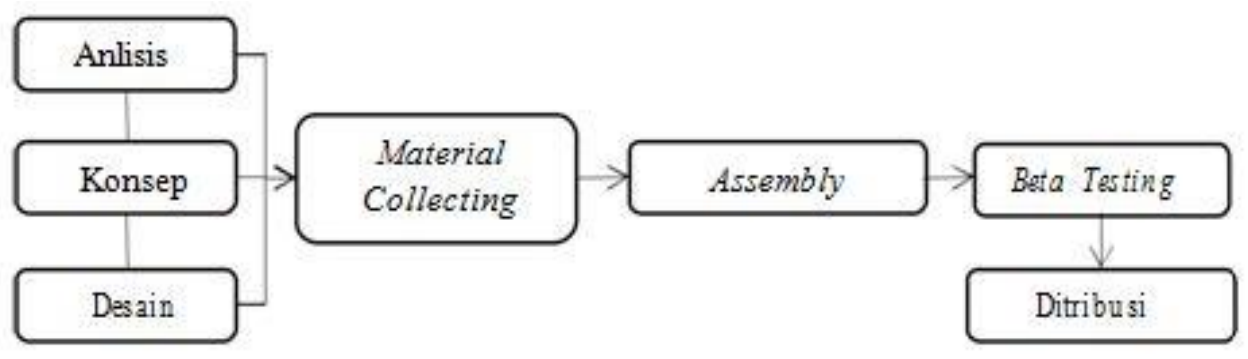

Gambar 3. Kerangka Penelitian

\subsection{Lokasi dan Waktu Penelitian}

Penelitian ini akan dilaksanakan di Sekolah Luar Biasa Negeri Bontang, Jalan Kapten Piere Tandean, Bontang Kuala, Bontang Kalimantan Timur. Penelitian direncanakan akan selesai pada kurun 3 bulan, Jangka waktu penelitian tersebut akan dimanfaatkan untuk menyelesaikan tahapantahapan mulai dari aktivitas persiapan penyiapan data proposal, pembuatan proposal, pengumpulan data, analisis dan pelaporan serta desiminasi hasil penelitian.

\subsection{Subjek dan Objek Penelitian}

Subjek dalam penelitian ini adalah Edutainment "Pengenalan Komputer" dengan menyajikan tiga jenis kegiatan yaitu kuis, mengetik, dan labirin. Sedangkan objeknya yaitu penerapan Algoritma Finite State Machine dan Shuffle Random dalam game labirin.

\subsection{Teknik Pengumpulan Data}

Data yang dikumpulkan terdiri atas data primer dan data sekunder. Data primer berasal dari lokasi pengkajian secara langsung, yang dilakukan melalui wawancara maupun kuisioner di Sekolah Luar Biasa Negeri Bontang, Jalan Kapten Piere Tandean, Bontang Kuala, Bontang Kalimantan Timur. Sedangkan data sekunder diperoleh dengan mempelajari studi literatur yang berupa aturan-aturan tertulis atau dokumen yang ada kaitannya judul penelitian.

\subsection{Teknik Analisis Data}

Analisis data kualitatif merupakan suatu analisa yang dilakukan dengan cara mencari hubungan ataupun pola dari sumber data yang telah ada untuk menjawab hipotesis kemudian disajikan deskriptif. Analisis data kualitatif merupakan suatu analisa yang dilakukan dengan cara mencari hubungan ataupun pola dari sumber data yang telah ada untuk menjawab hipotesis serta menyajikannya secara deskriptif [1].

Dalam mengembangkan hasil penelitian kualitatif maka langkah pertama yang harus dilakukan adalah mendeskripsikan fenomena berdasarkan data yang didapatkan. Disini peneliti menggunakan analisa statistik deskriptif. Statistik deskriptif adalah statistik yang digunakan untuk menganalisi data dengan cara mendeskripsikan atau menggambarkan data 
yang terkumpul sebagaimana adanya tanpa bermaksud membuat kesimpulan yang berlaku untuk umum atau generalisasi.

\subsection{Perancangan Antarmuka Edutainment "Pengenalan Komputer"}

Edutainment "Pengenalan Komputer" dirancang dengan tampilan yang menarik dan menggunakan layar komputer agar anak-anak berkebutuhan khusus dapat melihat tampilan game dengan sangat jelas. edutainment ini mengajarkan anak-anak berkebutuhan khusus dalam mengenal teknologi komputer serta disajikan game menarik untuk mengasah kemampuan mereka, terutama game labirin yang akan melatih kemampuan mereka dengan menyelesaikan misi jalan berliku. Ilustrasi perancangan tampilan edutainment "pengenalan komputer" dapat dilihat pada gambar 4 berikut ini.

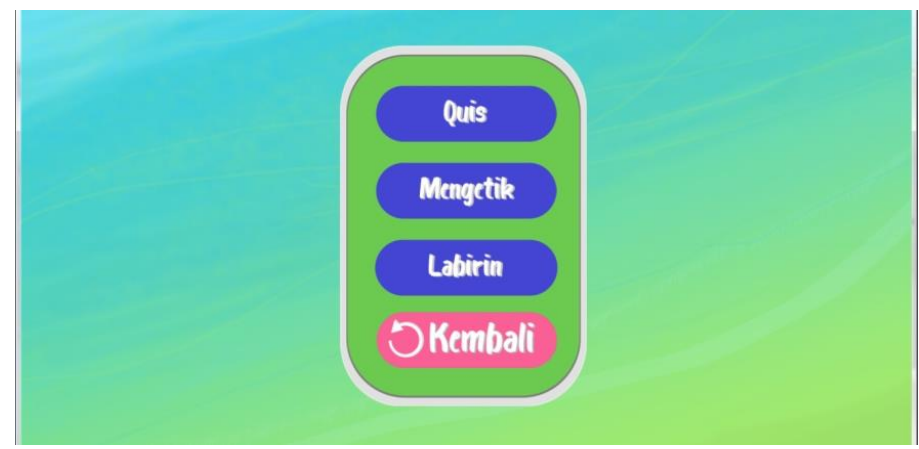

Gambar 4. Rancangan Tampilan Menu Utama

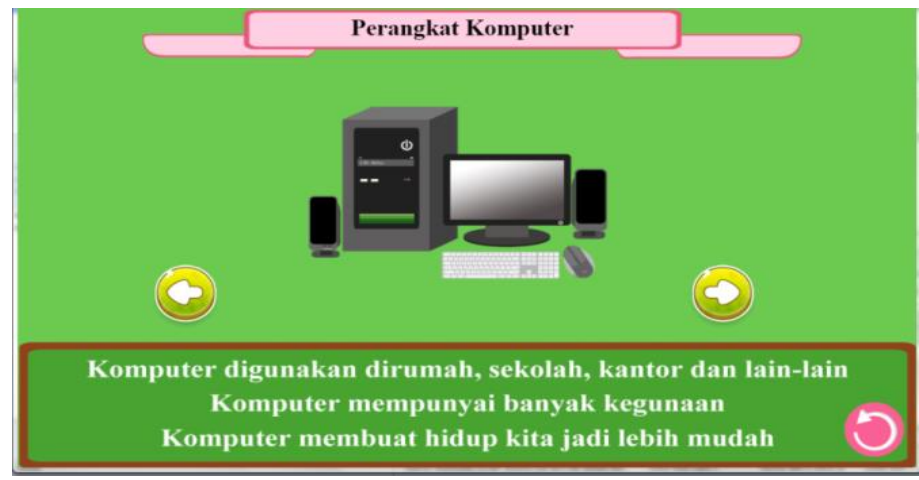

Gambar 5. Rancangan Menu Belajar

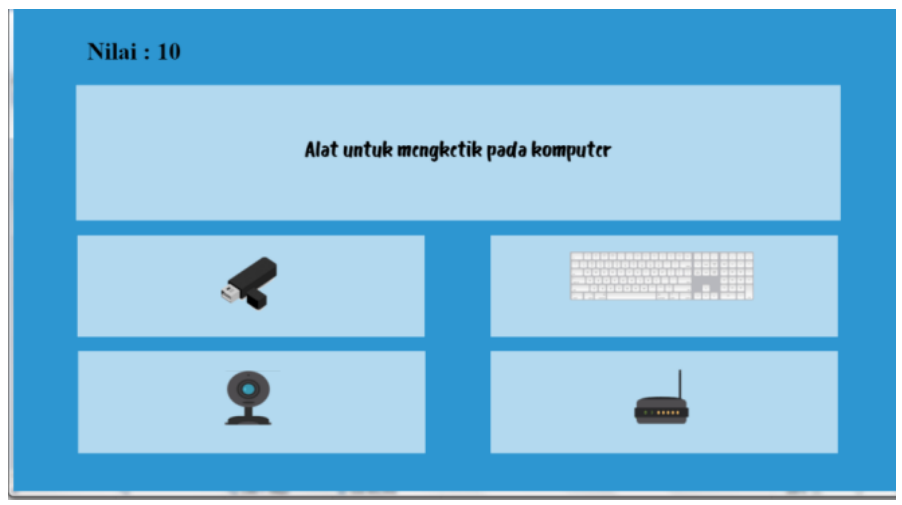

Gambar 6. Rancangan Game Kuis 


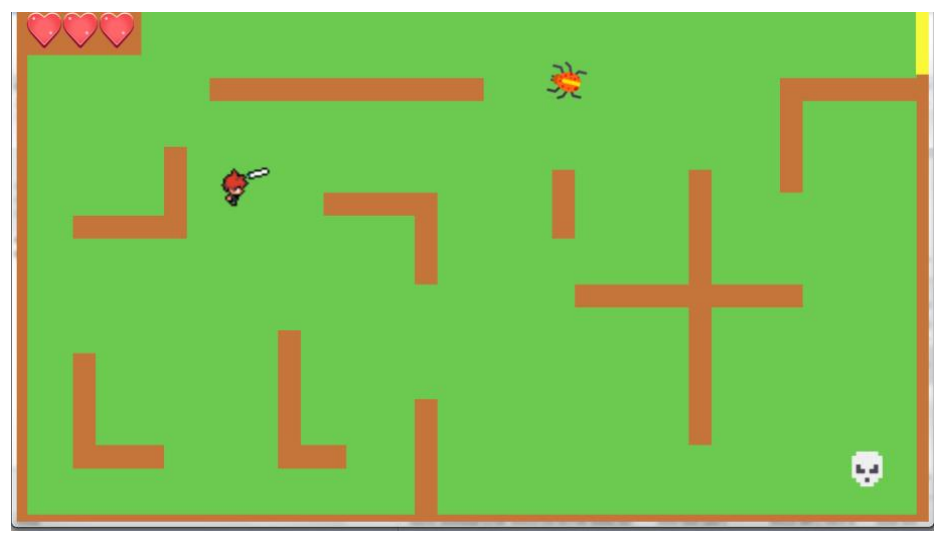

Gambar 7. Rancangan Game Labirin dengan menggunakan Intelligent Agent

\subsection{Perancangan Agent Finite State Machine}

Perancangan FSM didasarkan pada event yang terjadi pada log aktivitas anak saat belajar dan bermain. FSM karakter anak laki-laki anti virus. Berikut pada gambar 8 adalah rancangan state-state pada Finite State Machine yang akan diterapkan pada game "Pengenalan Komputer" untuk diagram user.

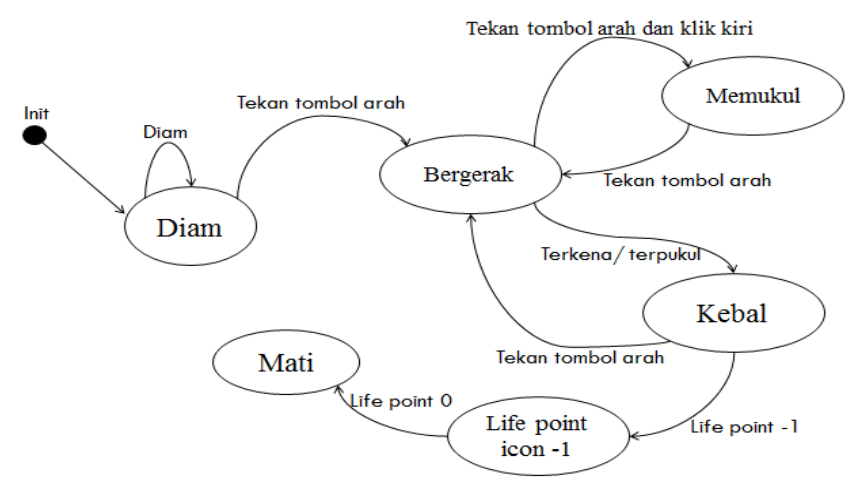

Gambar 8. Rancangan Diagram FSM User

Algoritma finite state machine pada diagram FSM user yaitu:

a) Permaian dimulai user diam.

b) Jika menekan tombol arah pada keyboard, makauser bergerak.

c) Jika tidak menekan tombol pada keyboard, maka user diam.

d) Jika menekan tombol arah pada kyeboard dan klik kiri pada mouse, maka user akan memukul.

e) Jika tidak menakan tombol arah pada keyboard dan klik kiri pada mouse, maka user diam.

f) Jika user terpukul musuh, maka user akan kebal, berkedip selama 1,5 detik dan life point berkurang 1.

g) Jika user tidak terpukul musuh, maka user (tidak kebal, tidak berkedip) dan life point tidak berkurang,

h) Jika life point berkurang 1, makaicon life point user berkurang 1.

i) Jika life point tidak berkurang, maka icon life point user tetap.

j) Jika life point $=0$, maka user mati.

k) Jikat life point tidak = 0, maka user tetap bermain. 


\section{SIMPULAN}

Edutainment penting bagi semua kalangan pada saat mereka bermain game bertemakan edutainment pada platform apa saja, disitu dengan tidak sengaja mereka akan mempelajari pengetahuan dalam bentuk permainan. Edutainment sangat menarik untuk dikembangkan, salah satu jenis yang digemari adalah game dengan genre simulasi yang didukung dengan kecerdasan buatan yang menggunakan Shuffle Random (SR) dan Finite State Machine (FSM) untuk mendukung interaksi dengan pemain. FSM terdiri dari serangkaian state yang menentukan keputusan. Berdasarkan pola yang dimiliki oleh game tersebut, pemain diharuskan untuk belajar sehingga dapat menyelesaikan permasalahan yang ada. Saat ini, ada banyak permainan yang mengedukasi sekaligus menghibur, sehingga memberikan inspirasi dalam pembuatan Edutainment "Pengenalan Komputer" sebagai media pembelajaran dengan teknik pengacakan Shuffle dan pengembangan agen cerdas menggunakan Finite State Machine. Dengan dibangunnya edutainment ini diharapkan para guru dapat terbantu dengan menarik minat anak tunagrahita ringan untuk belajar tentang perangkat komputer sambil bermain dengan menerapkan logika shuffle dalam permainan. Sedangkan intelligent agent akan memberikan respon, bertindak pada suatu kondisi tertentu sehingga terlihat seperti diri sendiri pada permainan labirin yang diimplementasikan dengan metode finite state machine.

\section{DAFTAR PUSTAKA}

[1] Hasibuan, Z. A. 2007. Metodologi Penelitian Pada Bidang Ilmu Komputer dan Teknologi Informasi : Konsep dan Aplikasi. Fakultas Imu Komputer Universitas Indonesia. Jakarta.

[2] Hurd, D dan Jenuings, E. 2010. Standardized Educational Games Ratings: Suggested Criteria. Longman. London.

[3] Kyaw, A.S. Peters, C. and Swe, T.N. 2013. Unity 4.x Game AI Programming. Packt Publishing Ltd. Birmingham.

[4] Poole, D.L. and Mackworth, A.K. 2010. Artificial Intelligence Foundations of Computational Agents. Cambridge University Press. New York.

[5] S Lailiyah, Y Yunita, S Mallala, R. Andrea. 2019. Probabilitas dalam Finite State Machine Agen Cerdas Edugame "Ajut-Ajut Kids". Jurnal Nasional Teknik Elektro dan Teknologi Informasi

[6] Rostianingsih, Silvia. 2013. Game Simulasi Finite State Machine Untuk Pertanian dan Peternakan. Surabaya: Universitas Kristen Petra.

[7] Rahadian, et.al. 2016. Penerapan Metode Finite State Machine Pada Game "The Relationship". Jurnal Informatika Mulawarman Samarinda: Universitas Mulawarman.

[8] Poole, D.L. and Mackworth, A.K. 2010. Artificial Intelligence Foundations of Computational Agents. Cambridge University Press. New York.

[9] Russell, S. J. and Norvig, P. 2011. Artificial Intelligence A Modern Approach Third Edition. Pearson Education, Inc. United States of America. 